though I couldn't stop thinking about the frogs.

On the plane home, I looked down at the receding Florida landscape. I wondered why those frogs had turned their backs on the purple waters that snake through the marshes near us. Why they had climbed up hot aluminum siding to squeeze through the crack of an abandoned trailer's win- dow. Probably for flies, I figured, and once they had gorged themselves on this unexpected feast, they must have been too fat to fit back through the crack. And so they were stuck there.

Their fate seemed to demonstrate some sort of cautionary tale, like "be careful what you wish for" or "the grass always looks greener," but to me they were a reminder that you can never go back. No matter how much you miss something or want it back, it never is the same. Yet how remarkable that after all this time under the scorching sun, a heart can still be red.

\section{Elizabeth Johnston}

Ms. Johnston is a writer who lectures at Concordia University in Montréal, Que.

\title{
The doctor in the street
}

S everal years ago, as a pediatric resident, I worked with a distinguished professor from whom I anticipated learning a great deal. I recall one busy day at the clinic, in the course of which my professor pointed out several "clinical pearls" arising from each case. During one of our conversations he thought I was being disrespectful to him. He informed me that I should remember I was not talking to the man on the street. My first thought was that he must be joking, but the flash of anger in his eyes told me otherwise. I was devastated; I apologized for any misunderstanding and assured him I had meant no disrespect. But a few moments later I began to feel angry. What made him think he was better than the man on the street? The man on the street would have treated me with more respect.

The rest of the day passed with minimal interaction between us, and the incident was not mentioned again.

Doctors are professionals; presumably, this is what separates us from many men or women in the street. A professional is someone with a defined set of knowledge and skills - a good communicator who exhibits honour and integrity, altruism, leadership, compassion, responsibility, accountability ... These were qualities I wanted to have. Certainly, I aspired to be a professional.

However, provoked by that exchange with the professor, I also started to pay more attention to the men and women I met in the street. A man gave me directions when I could not find my way. Another helped me to pick up my books when I dropped them. A woman stopped her car to let me cross more quickly on a rainy day. There were several such incidents. I wanted to be the woman in the street who was not too busy to give directions or to stop her car to let someone cross. Indeed, as a person in the street, I did extend such courtesies. But I began to wonder what sort of human being I was in the hospital.

A few months ago I was doing quick rounds on all the patients in the emergency department at the beginning of an evening shift. I went to assess a 14-year-old; he was in the resuscitation room, in a confused mental state. After ensuring that all the medical care was appropriate, I talked to the mother and asked if I could do anything for her. She said she needed to go to the washroom. As I turned to show her the way, she said, "Doctor, I don't want to leave him alone. He gets agitated if I don't hold his hands. Could you please sit with him and hold his hands until I get back?"

She was asking me, the attending staff physician at a busy tertiary care pediatric emergency department, to sit with her son for two minutes — just as she ते would ask any woman in the street. I sat down and took hold of her son's hands, feeling honoured.

\section{Savithiri Ratnapalan}

Division of Emergency Medicine

The Hospital for Sick Children

Toronto, Ont.

\section{A letter to cancer}

I watch for you,

Scoundrel.

You sneak and hide.

You tease and devour.

How do you choose your next morsel,

pick names

from a cosmic spinning drum

some of them more than once?

Why don't you beat it

to a decadent lair,

play video games

and

drink blood?

Or take an interplanetary vacation,

long and far

sip martinis

near the pounding purple surf, put up your scrawny gnarled legs and read a horror novel?

Leave us alone,

give it up

get your own life.

\section{Elisabeth Gold}

Assistant Professor

Department of Family Medicine and

Division of Medical Education

Dalhousie University

Halifax, NS 